\title{
Occupational Burnout Syndrome in Polish Physicians: A Systematic Review
}

\author{
Magdalena Zgliczyńska ${ }^{1,2}$, Stanisław Zgliczyński ${ }^{3}$, Michał Ciebiera ${ }^{1, * \mathbb{D}}$ \\ and Katarzyna Kosińska-Kaczyńska ${ }^{1}$ \\ 1 Second Department of Obstetrics and Gynecology, The Center of Postgraduate Medical Education, \\ 01-809 Warsaw, Poland; zgliczynska.magda@gmail.com (M.Z.); kasiakosinska@wp.pl (K.K.-K.) \\ 2 Chair and Department of Experimental and Clinical Physiology, Laboratory of Center for Preclinical \\ Research Medical University of Warsaw, 02-097 Warsaw, Poland \\ 3 Department of Internal Diseases and Endocrinology, Central Teaching Clinical Hospital, Medical University \\ of Warsaw, 02-097 Warsaw, Poland; stanislaw.zgliczynski@gmail.com \\ * Correspondence: michal.ciebiera@gmail.com; Tel.: +48-607-155-177
}

Received: 28 October 2019; Accepted: 4 December 2019; Published: 10 December 2019

check for updates

\begin{abstract}
Due to the nature of their work, physicians are exposed to chronic stress. This may potentially lead to the widespread occurrence of occupational burnout syndrome (BS). The aim of this systematic review study was to summarize available published data concerning the prevalence of BS in Polish doctors. The literature search was performed using the following databases: PubMed/MEDLINE, Scopus, Cochrane Central Register of Controlled Trials (CENTRAL) and Google Scholar. The last search was performed on September 27th, 2019. Only articles in English or Polish on graduated doctors practicing in Poland were taken into account. All types of original research were considered eligible. However, review articles, book chapters, case reports, case series, conference papers, study protocols and articles in languages other than English and Polish were excluded. There were no restrictions on age, seniority or specialty of study participants. The literature search revealed a total of 21 studies that met the inclusion criteria. The results of individual studies were very diverse, which makes it difficult to draw specific conclusions. However, the problem of burnout among Polish doctors is valid and worth special attention from society, health policy leaders, and doctors themselves. High-quality research is essential to for a better understanding of this topic.
\end{abstract}

Keywords: burnout; occupational burnout; depersonalization; emotional exhaustion; personal accomplishment; physicians; Poland

\section{Introduction}

The phenomenon of occupational burnout syndrome (BS) was first described in 1974 by Freudenberger [1], as a state of mental and physical exhaustion caused by one's professional life and exposure to prolonged stress. It was a trigger for further attempts to define this matter. Therefore, due to the complex nature of the condition, various concepts and definitions of BS have been developed to date and, consequently, also multiple diagnostic tools have been implemented. According to one of the most popular and widely recognized theories created by Maslach (1976), BS is a three-dimensional set of symptoms that occurs fairly regularly in people employed in occupations involving work in human services. It is characterized by emotional exhaustion (EE), depersonalization (DP) and a sense of low personal accomplishment (PA) [2]. The Maslach Burnout Inventory (MBI) for Human Services Survey is currently the most widely used tool for research in this field [3]. It allows the determination of the severity of the three above-mentioned BS symptoms. Gil Monte described a different perspective on BS. He created the Spanish Burnout Inventory (SBI) [4] and distinguished four areas of BS: enthusiasm 
toward the job, emotional exhaustion, indolence and guilt. The Italian Link Burnout Questionnaire (LBQ) by Santinello also considers four burnout aspects, which are distinct from SBI: psychophysical exhaustion, deterioration of relationships, sense of professional failure and disillusion [5]. On the other hand, Steuden and Okła distinguished five BS manifestations: reduced emotional control, loss of subject's commitment, decreased effectiveness, limited interpersonal contacts and physical fatigue [6]. For the purpose of the unification of this review, the authors decided to focus primarily on the concepts used in the data included.

Due to the nature of their work, physicians are a professional group that is highly exposed to BS. According to a recently published systematic review, the overall BS prevalence in physicians ranged from $0 \%$ up to even $80.5 \%$ [7]. The review included only one study on the population of Polish doctors by Glebocka [8]. Polish physicians might to be particularly vulnerable to BS due to the poor condition of the healthcare system in Poland. According to the latest Euro Health Consumer Index 2018, which is an attempt at measuring the performance of the healthcare system, the Polish healthcare system was ranked 32nd out of the 35 countries included in the report [9]. In 2016, Poland was one of the European Union (EU) countries with the lowest health expenditure per capita, with only Latvia, Romania, Bulgaria and Croatia ranking lower $[10,11]$. Moreover, numbers of practicing doctors are lower compared to the majority of neighboring countries and, admittedly, insufficient. In 2016, Poland had one of the lowest ratio of practicing physicians per 1000 people among the EU countries-2.4 compared to the average of 3.6 in the EU [12,13]. This contributed to repeated strikes by Polish doctors in the past few years in which the following postulates were presented: Increased expenditures on healthcare; achievement of average indicators of the length and quality of life at least at the level of the European Union; higher standards of care and prevention; solving the problem of shortages in medical staff; and improvement in working conditions and wages [14-17].

Delving into the essence of this problem seemed particularly important to the authors as physicians' well-being is considered as a forgotten quality factor in healthcare [18]. It was proved that BS may lead to reduced quality of life in physicians $[19,20]$, the occurrence of depression symptoms [21] or even suicidal behaviors [22]. Even the potential overlapping of depression and burnout is also being widely discussed [21,23]. There is evidence that it negatively correlates with the feeling of empathy for patients [24]. Moreover, it may influence patient satisfaction and interpersonal aspects of care $[25,26]$. Furthermore, it can be associated with reduced work efficiency $[27,28]$, an increased frequency of medical errors [29-32] and worse patient outcomes [33,34].

The aim of this systematic review study was to summarize available data concerning the occurrence of BS in the population of physicians working in Poland.

\section{Materials and Methods}

The systematic literature review of research articles concerning the phenomenon of BS in Polish physicians was performed with the use of the following databases: PubMed/MEDLINE, Scopus, Cochrane Central Register of Controlled Trials (CENTRAL) and Google Scholar. The last search was performed on September 27th, 2019. It was not necessary to contact the authors of selected works to obtain additional information. This review was written in accordance with the Preferred Reporting Items for Systematic Reviews and Meta-Analyses (PRISMA) statement.

The search strategy was tailored to the specific database (details provided in Table 1).

Table 1. Full electronic search strategy.

\begin{tabular}{|c|c|c|}
\hline Database & Number of Results & Search Strategy \\
\hline Pubmed & 135 & $\begin{array}{l}\text { ("Physicians"[Mesh] OR doctor OR physician OR specialist } \\
\text { OR healthcare professional OR health professional) AND } \\
\text { ("Burnout, Professional"[Mesh] OR “Burnout, } \\
\text { Psychological"[Mesh] OR burnout OR burned out) AND } \\
\text { ("Poland"[Mesh] OR Poland OR Polish) }\end{array}$ \\
\hline
\end{tabular}


Table 1. Cont.

\begin{tabular}{|c|c|c|}
\hline Database & Number of Results & Search Strategy \\
\hline Scopus & 92 & $\begin{array}{l}\text { (TITLE-ABS-KEY (doctor* OR physician* OR specialist* OR } \\
\text { (healthcare AND professional*) OR (health AND } \\
\text { professional*)) AND TITLE-ABS-KEY (burnout OR (burned } \\
\text { AND out)) AND TITLE-ABS-KEY (Poland OR Polish)) }\end{array}$ \\
\hline CENTRAL & 2 & $\begin{array}{c}\text { \#1 } 1^{* *} \text { “Physicians"[Mesh] } \\
\text { \#2 doctor* OR physician* OR specialist* OR (healthcare AND } \\
\text { professional*) OR (health AND professional*) } \\
\text { \#3 “Burnout, Professional”[Mesh] } \\
\text { \#4 “Burnout, Psychological”[Mesh] } \\
\text { \#5 burnout OR (burned AND out) } \\
\text { \#6 “Poland”[Mesh] } \\
\text { \#7 Poland OR Polish } \\
\text { \#8 (\#1 OR \#2) AND (\#3 OR \#4 OR \#5) AND (\#6 OR \#7) }\end{array}$ \\
\hline $\begin{array}{l}\text { Google Scholar } \\
\text { (in English) }\end{array}$ & First $50^{*}$ & $\begin{array}{l}\text { (doctor* OR physician* OR specialist* OR (healthcare AND } \\
\text { professional }^{*} \text { ) OR (health AND professional*)) AND (burnout } \\
\text { OR (burned AND out) AND (Poland OR Polish)) }\end{array}$ \\
\hline $\begin{array}{l}\text { Google Scholar } \\
\text { (in Polish) }\end{array}$ & First $50^{* *}$ & $\begin{array}{l}\text { (wypalenie OR (wypalenie AND zawodowe)) AND (lekarz* } \\
\text { OR specjalist*) AND (Polska OR polsk* OR polsc*) }\end{array}$ \\
\hline
\end{tabular}

${ }^{*}$ Review of 50 first results out of 63,600 arranged in default order by database algorithms; ${ }^{* *}$ Review of 50 first results out of 429 arranged in default order by database algorithms. ${ }^{* *}$ Subsequent numbers correspond to successive lines entered in the CENTRAL search engine.

All types of original research articles were considered eligible. Review articles, book chapters, case reports, case series, conference papers and study protocols were excluded from further considerations. Only articles written in English or Polish were taken into account. No publication date restrictions were imposed. Only studies on graduated doctors practicing in Poland were taken into account, while research articles on mixed groups of healthcare professionals, other medical professions and students of medicine and other faculties related to health care were excluded from further analyses. There were no restrictions on the age, length of service or specialty of study participants.

Titles and abstracts of research papers obtained as a result of the search described above were screened independently by two study authors. Full-text versions of studies that appeared to be potentially eligible based on the first stage of evaluation were individually assessed by three other authors. For each study, two authors collected the baseline characteristics of participants and outcomes. The developed data extraction sheet was pilot-tested on five randomly-selected included studies and refined accordingly. Extracted information included: study population and comparator demographics, recruitment, methodology, diagnostic tools used and outcomes.

Two authors individually assessed the risk of bias in selected studies using a modified version of the Newcastle-Ottawa Scale [35] based on a large systematic review on a similar topic-"Prevalence of Burnout Among Physicians. A Systematic Review" by Rotenstein et al. [7]—additionally adapted by the authors for the needs of this systematic review. Any disagreements were resolved through discussion and consensus with all study authors.

\section{Results}

\subsection{Database Search Results}

The designed systematic literature search identified a total of 21 studies that met all the inclusion criteria. Selected studies included a total of 1674 doctors practicing in Poland, of at least 14 different specialties. Two series of publications referred to the same study group: the first one consisted of 2 publications, the second one consisted of 5 publications. The search of PubMed/MEDLINE, Scopus, Cochrane Central Register of Controlled Trials (CENTRAL) and Google Scholar provided a total of 
329 citations. After adjusting for duplicates (using an automatic EndNote X9 duplicate search followed by manual verification), 220 remained, of which 66 full-text articles were assessed for eligibility. Other details regarding the selection process are included in the adapted PRISMA flow chart presented in Figure S1.

\subsection{General Characteristics of the Included Studies}

A summary of the characteristics of research articles included in the review is provided in Table 2.

Table 2. Characteristics of the research articles included in the review.

\begin{tabular}{|c|c|c|c|c|}
\hline Study & $\begin{array}{c}\text { Final Number of Examined } \\
\text { Physicians and Gender } \\
\text { Distribution }\end{array}$ & Age $^{*}$ & Specialty & Seniority * \\
\hline [36] & $\begin{array}{c}70 \\
\$ 66 \% \\
0^{7} 34 \% \\
\end{array}$ & $\begin{array}{l}\text { Range } \\
27-61\end{array}$ & Radiology & 12 \\
\hline [37] & 51 & 40 & Psychiatry & 9 \\
\hline [38] & $\begin{array}{c}41 \\
\uparrow 56 \% \\
\sigma^{2} 44 \%\end{array}$ & 38 & Various & 15 \\
\hline [39] & $\begin{array}{c}84 \\
\text { } 48 \% \\
\sigma^{2} 52 \%\end{array}$ & $\begin{array}{l}=<40-28 \% \\
40-50-43 \% \\
=>50-29 \%\end{array}$ & $\begin{array}{c}\text { Neurology-29\% } \\
\text { Cardiology-29\% } \\
\text { Orthopedics-24\% } \\
\text { Endocrinology-19\% }\end{array}$ & LoD \\
\hline [40] & 55 & $\begin{array}{l}\text { Range } \\
27-60\end{array}$ & $\begin{array}{l}\text { Internal medicine, surgery, } \\
\text { pediatrics, social welfare home }\end{array}$ & $\begin{array}{l}\text { Range } \\
1-30\end{array}$ \\
\hline [41] & 150 & LoD & $\begin{array}{l}\text { Full-time general practitioners } \\
\text { or family medicine }\end{array}$ & LoD \\
\hline [42] & $\begin{array}{c}82 \\
\text { ○59\% } \\
\sigma^{2} 41 \%\end{array}$ & 37 & $\begin{array}{l}\text { Surgery, orthopedics- } 44 \% \\
\text { Internal medicine, psychiatry, } \\
\text { family medicine, } \\
\text { oncology-56\% }\end{array}$ & 11 \\
\hline [43] & $\begin{array}{c}66 \\
+71 \% \\
\sigma^{7} 29 \% \\
\end{array}$ & 48 & $\begin{array}{c}\text { Anesthesiology-52\% } \\
\text { Dermatology, } \\
\text { ophthalmology-48\% }\end{array}$ & $\begin{array}{r}1-13-53 \% \\
14-28-35 \% \\
29-43-12 \%\end{array}$ \\
\hline$[44]$ & $\begin{array}{c}71 \\
+35 \% \\
\sigma^{7} 64 \%\end{array}$ & $\begin{array}{l}\text { Range } \\
25-68\end{array}$ & $\begin{array}{l}\text { Primary care- }-41 \% ; \\
\text { Non-surgical-32\%; } \\
\text { Surgical-27\% }\end{array}$ & LoD \\
\hline$[45]$ & $\begin{array}{c}136 \\
\text { o52\% } \\
\sigma^{7} 48 \%\end{array}$ & 49 & Anesthesiology & 23 \\
\hline $\begin{array}{l}\text { Series: } \\
{[46-50]}\end{array}$ & $\begin{array}{c}54 \\
\text { o69\% } \\
\sigma^{7} 31 \% \\
\end{array}$ & 29 & Various & LoD \\
\hline [8] & 48 & 43 & LoD & LoD \\
\hline $\begin{array}{l}\text { Series: } \\
{[51]} \\
{[52]}\end{array}$ & $\begin{array}{c}373 \\
\$ 58 \% \\
0^{7} 42 \%\end{array}$ & $\begin{array}{l}42 \text { in the whole } \\
\text { study group }\end{array}$ & Anesthesiology & 16 \\
\hline [53] & 50 & LoD & Various & LoD \\
\hline$[54]$ & $\begin{array}{c}25 \\
+64 \% \\
036 \% \\
\end{array}$ & 37 & Emergency Medical Services & 11 \\
\hline [55] & $\begin{array}{l}318 \\
+66 \% \\
\sigma^{\top} 34 \%\end{array}$ & 47 & $\begin{array}{c}42 \text { different specialties, } \\
\text { including: } 18 \% \text { of psychiatry, } \\
16 \% \text { of internal medicine, } \\
13 \% \text { of pediatrics }\end{array}$ & LoD \\
\hline
\end{tabular}

${ }^{*}$ Mean unless stated otherwise. Abbreviations: o—women; $0^{\star}-$ men; BS—burnout syndrome; DP-depersonalization;

EE—emotional exhaustion; LoD—lack of data; MBI—Maslach Burnout Inventory; PA—personal accomplishment. 


\subsection{Summary of Individual Study Results}

The results of studies that considered the prevalence and severity of BS are summarized in the table below (Table 3).

Table 3. Prevalence and the severity of burnout syndrome (BS).

\begin{tabular}{|c|c|c|c|c|}
\hline Study & $\begin{array}{l}\text { Main Burnout } \\
\text { Assessment Tool }\end{array}$ & $\begin{array}{l}\text { Level of Burnout } \\
\text { Definition }\end{array}$ & $\begin{array}{l}\text { Prevalence and } \\
\text { Severity of BS in } \\
\text { Physicians }\end{array}$ & $\begin{array}{l}\text { Severity of BS Components } \\
\text { in Physicians }\end{array}$ \\
\hline [40] & $\begin{array}{l}\text { MBI version not } \\
\text { specified }\end{array}$ & & & $\begin{array}{l}\text { High EE: } 22 \% \\
\text { High DP: } 62 \%\end{array}$ \\
\hline [41] & $\begin{array}{l}\text { 22-item } \\
\text { MBI for Human } \\
\text { Services Survey } \\
\text { Polish translation }\end{array}$ & $\begin{array}{c}\text { EE: low }<13 \text {, average 14-26, } \\
\text { high }>27 \\
\text { DP: low }<5 \text {, average 6-9, } \\
\text { high }>10 \\
\text { PA: high }<33 \text {, average } 34-39, \\
\text { low }>40\end{array}$ & & $\begin{array}{l}\text { High EE: } 48 \% \\
\text { High DP: } 34 \% \\
\text { Low PA: } 30 \%\end{array}$ \\
\hline [42] & $\begin{array}{l}\text { 22-item } \\
\text { MBI Polish } \\
\text { adaptation by } \\
\text { Pasikowski }\end{array}$ & $\begin{array}{l}\text { Scores trichotomized with } \frac{1}{2} \\
\text { of SD above and below the } \\
\text { mean as cut points }\end{array}$ & & $\begin{array}{l}\text { High EE: } 52 \% \\
\text { High DP: } 35 \% \\
\text { Low PA: } 34 \%\end{array}$ \\
\hline [8] & $\begin{array}{l}\text { MBI version } \\
\text { not specified }\end{array}$ & & & $\begin{array}{l}\text { High EE: } 33 \% \\
\text { High DP: } 35 \% \\
\text { High PA: } 32 \%\end{array}$ \\
\hline [37] & $\begin{array}{l}\text { 22-item MBI Polish } \\
\text { adaptation by } \\
\text { Pasikowski }\end{array}$ & & & $\begin{array}{c}\text { For the nurses + physicians } \\
\text { Mean: } \\
\text { EE: 22, DP: 5, PA: } 30\end{array}$ \\
\hline [38] & $\begin{array}{l}\text { 22-item MBI Polish } \\
\text { adaptation by } \\
\text { Pasikowski }\end{array}$ & & & $\begin{array}{c}\text { Mean: } \\
\text { कEE: } 20 \text { o }^{{ }^{\top} \mathrm{EE}:} 21 \\
\text { कDP: } 8 \text { o }^{\top} \mathrm{DP}: 9\end{array}$ \\
\hline [43] & $\begin{array}{l}\text { 22-item } \\
\text { MBI version not } \\
\text { specified }\end{array}$ & $\begin{array}{c}\text { High overall stress } \\
\geq 49\end{array}$ & $\begin{array}{l}\text { Mean overall result } \\
\text { Anesthesiologists: } 52 \\
\text { Other specialties: } 41\end{array}$ & $\begin{array}{c}\text { Anesthesiologists: } \\
\text { Mean EE: 27, DP: 9, PA: } 16 \\
\text { Other specialties: } \\
\text { Mean EE: 20, DP: 7, PA: } 15\end{array}$ \\
\hline [44] & $\begin{array}{l}\text { 22-item } \\
\text { MBI version not } \\
\text { specified }\end{array}$ & & $\begin{array}{l}\text { Mean overall results: } \\
\text { Surgical specialties: } 58 \\
\text { Non-surgical: } 59 \\
\text { Primary care: } 53\end{array}$ & $\begin{array}{c}\text { Surgical: } \\
\text { Mean EE: 20, DP: 8, PA: } 29 \\
\text { Non-surgical: } \\
\text { Mean EE: 22, DP: 9, PA: } 28 \\
\text { Primary care: } \\
\text { Mean EE: 22, DP: 10, PA: } 29\end{array}$ \\
\hline [36] & $\begin{array}{l}\text { 66-item } \\
\text { Burnout Scale by } \\
\text { Studen and Okła }\end{array}$ & $\begin{array}{c}\text { Stens scale: } \\
\text { low }<4, \text { medium } 4-6, \\
\text { high }>6 \\
\text { overall result: } \\
\text { low }<3.34 \text {, medium } \\
3.34-6.66, \text { high }>6.66\end{array}$ & $\begin{array}{c}\text { Low: } 11 \% \\
\text { Medium: } 51 \% \\
\text { High: } 37 \% \\
\\
\text { All symptoms at a high } \\
\text { level: } 16 \% \\
\end{array}$ & $\begin{array}{l}\text { High level of: } \\
\text { - PF: } 53 \% \\
\text { - RE: } 41 \% \\
\text { - LC: } 40 \% \\
\text { - RC: } 40 \% \\
\text { - SC: } 36 \%\end{array}$ \\
\hline [39] & $\begin{array}{l}\text { 66-item } \\
\text { Burnout Scale by } \\
\text { Studen and Okła }\end{array}$ & $\begin{array}{l}\text { Moderate 4-6 stens; } \\
\text { Theoretical average for this } \\
\text { scale }-132\end{array}$ & $\begin{array}{l}\text { Most examined } \\
\text { doctors do not } \\
\text { experience significant } \\
\text { burnout (mean 138) }\end{array}$ & $\begin{array}{l}\text { Stens: } \\
\text { - PF: } 6 \\
\text { - RE: } 6 \\
\text { - LC: } 6 \\
\text { - RC: } 5 \\
\text { - LC: } 5\end{array}$ \\
\hline [53] & $\begin{array}{c}24 \text {-item } \\
\text { Polish adaptation of } \\
\text { Link Burnout } \\
\text { Questionnaire }\end{array}$ & & $\begin{array}{c}\text { Mean: } 60 \\
\text { (maximum 144) }\end{array}$ & \\
\hline [55] & $\begin{array}{c}\text { 24-item } \\
\text { Polish adaptation of } \\
\text { Link Burnout } \\
\text { Questionnaire }\end{array}$ & $\begin{array}{l}\text { High } \\
\geq 8 \text { stens }\end{array}$ & $\begin{array}{l}\text { Every second doctor } \\
\text { showed high level of } \\
\text { BS }\end{array}$ & $\begin{array}{c}\text { High level of: } \\
\text { - psychophysical exhaustion: } 43 \% \\
\text { - commitment to relationship with } \\
\text { patients: } 44 \% \\
\text { - effectiveness in work: } 47 \% \\
\text { - existential expectations: } 48 \%\end{array}$ \\
\hline
\end{tabular}


Table 3. Cont.

\begin{tabular}{|c|c|c|c|c|}
\hline Study & $\begin{array}{l}\text { Main Burnout } \\
\text { Assessment Tool }\end{array}$ & $\begin{array}{l}\text { Level of Burnout } \\
\text { Definition }\end{array}$ & $\begin{array}{l}\text { Prevalence and } \\
\text { Severity of BS in } \\
\text { Physicians }\end{array}$ & $\begin{array}{l}\text { Severity of BS Components } \\
\text { in Physicians }\end{array}$ \\
\hline $\begin{array}{l}\text { Series } \\
{[51,52]}\end{array}$ & $\begin{array}{c}\text { 20-item } \\
\text { Polish adaptation of } \\
\text { Spanish Burnout } \\
\text { Inventory }\end{array}$ & $\begin{array}{l}\text { Critical level- values equal } \\
\text { to or higher than 90th } \\
\text { percentile }\end{array}$ & High or critical: $18 \%$ & $\begin{array}{c}\text { The weakest possible rating of: } \\
\text { - enthusiasm towards job: } 20 \% \\
\text { - psychological exhaustion: } 11 \% \\
\text { - indolence: } 13 \% \\
\text { - feeling of guilt: } 6 \%\end{array}$ \\
\hline
\end{tabular}

Abbreviations: BS-burnout syndrome; DP-depersonalization, EE-emotional exhaustion, LC-limited interpersonal contacts; MBI—Maslach Burnout Inventory; PA—personal accomplishment; PF—physical fatigue; $\mathrm{RE}$-reduced effectiveness of action; RC—reduced emotional control; SC—loss of subject's commitment.

\subsection{Risk and Protective Factors against BS}

The vast majority of articles determined risk as well as protective factors for the occurrence of BS. Details are provided in Table 4.

Table 4. Risk and protective factors for BS.

\begin{tabular}{|c|c|c|}
\hline Study & $\begin{array}{l}\text { Factors Contributing to the More Frequent or } \\
\text { Increased Incidence of BS }\end{array}$ & Protective Factors \\
\hline [36] & $\begin{array}{l}\text { - practicing } 10-20 \text { years } \\
\text { - number of workplaces }\end{array}$ & - long work experience ( $\geq 20$ years) \\
\hline [37] & $\begin{array}{c}\text { - work overload } \\
\text { - negative affectivity } \\
\text { - female (higher level of stress) } \\
\text { - lack of rewards } \\
\text { - physical burden } \\
\text { - unpleasant work conditions } \\
\text { - type D personality }\end{array}$ & \\
\hline [38] & $\begin{array}{c}\text { - sense of loss resources in last } 12 \text { months: } \\
\text { hedonistic and vital, spiritual, family, } \\
\text { material and political, power and prestige } \\
\text { - cynicism }\end{array}$ & \\
\hline [39] & - specialty (neurology) & $\begin{array}{l}\text { - high score in Generalized } \\
\text { Self-Efficacy Scale }\end{array}$ \\
\hline [40] & & - strong internal locus of control \\
\hline [41] & $\begin{array}{c}\text { - low job satisfaction } \\
\text { - not having further qualification }\end{array}$ & \\
\hline [42] & $\begin{array}{l}\text { - high level of psychophysical demands } \\
\text { and of requirements associated with } \\
\text { responsibility for other people's safety } \\
\text { - female (lower self-perceived } \\
\text { personal accomplishment) }\end{array}$ & $\begin{array}{l}\text { - high level of intellectual demands, } \\
\text { - individual cognitive control } \\
\text { - high level of support provided by } \\
\text { superiors and co-workers } \\
\text { - self-enhancing humor style }\end{array}$ \\
\hline [43] & - shorter professional experience & \\
\hline$[44]$ & - non-surgical specialty & - high level of empathy \\
\hline [45] & - high workload (>60 hours a week) & $\begin{array}{l}\text { - satisfaction with social life } \\
\text { - good health }\end{array}$ \\
\hline
\end{tabular}


Table 4. Cont.

\begin{tabular}{|c|c|c|}
\hline Study & $\begin{array}{l}\text { Factors Contributing to the More Frequent or } \\
\text { Increased Incidence of BS }\end{array}$ & Protective Factors \\
\hline $\begin{array}{l}\text { Series: } \\
{[46-50]}\end{array}$ & $\begin{array}{l}\text { 2011: low level of the sense of } \\
\text { comprehensibility in the 6th, high level of } \\
\text { "trait" anxiety in the 4th, high level of } \\
\text { depression in the 3rd, low need for social } \\
\text { approval in the 3rd year of medical school } \\
\text { 2012: } \\
\text { - type of career "Committed-satisfied with } \\
\text { career"-the most committed to their work } \\
\text { with the highest level of work stress }\end{array}$ & $\begin{array}{c}2012 \text { : } \\
\text { - type of career "Clever-satisfied with } \\
\text { life" - the least committed to their } \\
\text { work, but deriving the most } \\
\text { benefit from it } \\
\text { - well-being and life satisfaction } \\
\text { 2014: } \\
\text { - high sense of coherence at } \\
\text { medical studies } \\
2016 \text { : } \\
\text { - taking actions and dealing directly } \\
\text { with the problem at medical studies } \\
2018 \text { : } \\
\text { - family, freedom, happiness, mature } \\
\text { love, self-respect, social recognition } \\
\text { and wisdom }\end{array}$ \\
\hline [8] & $\begin{array}{c}\text { - negative assessment of healthcare, } \\
\text { - poor relationships between } \\
\text { healthcare professionals } \\
\text { - positive assessment of conditions } \\
\text { offered to in-patients } \\
\text { - positive patients' attitude toward physicians } \\
\text { - negative patients' attitude toward nurses }\end{array}$ & $\begin{array}{l}\text { - seniority } \\
\text { - positive general assessment } \\
\text { of healthcare, } \\
\text { - negative assessment of patients' } \\
\text { attitude toward physicians } \\
\text { - proper relationship between } \\
\text { healthcare professionals }\end{array}$ \\
\hline [55] & $\begin{array}{l}\text { - high level of perceived stress } \\
\text { - large number of duties per month }\end{array}$ & $\begin{array}{c}\text { - seniority } \\
\text { - frequent use of annual leave }\end{array}$ \\
\hline
\end{tabular}

\subsection{Risk of Bias Assessment}

The risk of bias assessment was performed using a modified version of the Newcastle-Ottawa Scale [35] based on Rotenstein et al. [7] and adapted by the authors for this review. A detailed bias assessment is available in Table S1 and Table S2. Nevertheless, a vast majority of the studies were of medium or low credibility. We evaluated five aspects: representativeness, sample size, non-respondent description, tools used for the detection of BS and statistics. Possible scores in each category were 0 or 1 point. Only one study obtained the maximum number of points (5/5). Two series of articles (two and five articles each) and one separate article received $4 / 5$ points. Three and two points were scored by five and seven studies, respectively. All studies were cross-sectional, and therefore constituted a III Level of Evidence, which indicates a B/C Grade of Recommendation.

\section{Discussion}

The scientific papers included in this review differ primarily in their methodology, as well as in results. Six different tools were used to examine the level of BS in Polish physicians and, in addition, the most popular tool-MBI-also appeared in a few different versions. The following paragraphs are an attempt to interpret the collected results with a division into sub-sections.

\subsection{BS in Physicians in Poland and Worldwide}

As it was mentioned, at present Polish health care is facing many problems. That is why we considered it important to determine whether Polish doctors are therefore particularly vulnerable to burnout. There is a lot of evidence that exposure to BS varies depending on the country [56-58]. In a large meta-analysis by Rotenstein et al., overall BS stratified by country ranged from $4 \%$ in Peru up to $61 \%$ in Canada. Similarly, large differences could be found in classic BS components (EE: 14\%—Peru and 72\%—Palestine; DP: 9\%-Greece, 35\%—Poland and 79\%-Turkey; sense of low 
PA: $8 \%$-Australia and 77\%-India) [7]. In our review few papers reported the overall BS occurrence. In a study by Makara-Studzinska et al. every second physician showed a high level of BS [55], while Czekajska-Chehab et al. reported 37\% of the examined population [36]. On the other hand, Leszczynski et al. reported 16\% [54], whereas Misiolek et al. reported 18\% [52]. Nevertheless, a vast majority of the articles focused on the severity of individual symptoms. A high level of EE in Polish doctors in research articles included in this review ranged from 22\% [40] to 52\% [42], whereas a high level of DP oscillated between $34 \%$ [41] and $62 \%$ [40]. A large dispersion could result from study population variety and different diagnostic tools and cut-off points used as presented in Table 3. Only one study containing a direct comparison of Polish physicians to physicians from other countries was identified. In a study by Soler et al., Polish general practitioners and family doctors were scored as the 4th highest in terms of the severity of EE, 8th in terms of DP and 5th in terms of PA out of doctors from 12 European countries [41]. Nevertheless, more high-quality comparisons are necessary to reach any consensus on this matter.

\subsection{Gender and BS in Physicians}

A meta-analysis published by Purvanova et al. on the relationship between gender and BS in various other professions revealed slightly higher EE in women; however, at the same time, a lower level of DP [59]. However, the situation in the medical environment is not entirely clear. The recent Medscape National Physician Burnout, Depression and Suicide Report (2019) on over 15,000 doctors showed that burnout was self-reported by $50 \%$ of women and $38 \%$ of men physicians. In the scientific literature, studies reporting either no significant differences between the sexes $[60,61]$ as well as indications that female doctors are more sensitive to burnout [62-64] are also available. Among the studies included in this review results also varied. Misiolek et al. did not find significant differences between male and female doctors in any variable $[51,52]$ while the international study by Soler et al., which also included Polish doctors, pointed to the male sex as being a BS risk factor [41]. Conversely, studies suggesting that female doctors may suffer from a higher severity of EE [37] and lower satisfaction from PA [37,42] in comparison to male doctors were also retrieved. Such divergent results obtained on different populations may result, for example, from the medical specialty of the studied group or cultural background. Nevertheless, the Supreme Medical Council of Poland report of 10 September 2019 shows that up to 58\% of doctors practicing in Poland are women [65]. Despite the lack of a final conclusion in this matter, it may be worth looking more closely for BS symptoms in this group, particularly in the face of growing staff shortages in Poland.

\subsection{Specialty and BS in Physicians}

The retrieved studies suggested a higher risk of BS in anesthesiologists [43] and neurologists [39], which was also reflected in studies from other countries [66,67]. However, it should be noted that articles selected for this systematic review did not cover all medical specialties. Nevertheless, in a study conducted by Walocha et al. [44], the highest overall level of burnout was found in non-surgical specialists. Worldwide, research has indicated some medical specialties associated with a particular burden, which are, among others: front line of healthcare (family medicine, internal medicine, emergency medicine) [68], cancer professionals [69], psychiatry [70] and surgery [71].

Currently, Polish doctors can undertake postgraduate education in 77 different specializations. Our survey covered at least 14, though we still lack a full view. Except specialization itself, the setting of the medical practice may also play a significant role [71,72]. Currently, many Polish doctors tend to work only in the private sector, with greatly different work characteristics than in the public sector, and such comparisons have not been yet thoroughly investigated.

\subsection{Professional Experience and BS in Physicians}

In a study by Wojtyna et al. [42] no differences were found between doctors during specialty training and specialists. Conversely, Mroz et al. reported a worse overall BS score and lower PA in 
doctors with shorter work experience, which was also confirmed by Makara-Studzinska et al. [43,55]. Furthermore, in a study by Głębocka et al. seniority was positively correlated with satisfaction from PA [8]. Reports of a higher incidence of BS in residents and physicians with shorter professional experience were also published on other populations. This relationship applies to both surgical and non-surgical specialties [73-75]. However, Dyrbye et al. conducted a survey in a large group of over 7000 doctors and found middle career (11-20 years in profession) to be particularly challenging time for doctors [76], also when analyzed by gender, specialty or setting. In the retrieved studies a very similar observation was made by Czekajska-Czehab et al. [36].

\subsection{Working Time and BS in Physicians}

Three of the selected studies indicated a relationship between the length of work or the number of jobs and the occurrence of BS in Polish doctors. The working hours along with the number of jobs, as well as shifts were assumed to be related to the risk of BS $[36,45,55]$. Ogińska-Bulik also emphasized that even a sense of work overload was associated with a more common occurrence of EE [37]. In addition, Makara-Studzinska et al. showed a protective effect of frequent use of annual leave [55]. Unfortunately, currently in Poland about 1 in 5 doctors reached retirement age [65], which will probably contribute to widening the existing staff shortages, a greater workload of active professional doctors and, as a result, often longer working hours.

\subsection{Personality, Coping Strategies and Personal Resources and BS in Physicians}

The articles contained in this systematic review identified a variety of other BS risk as well as protection factors.

In an series of publications on the type of careers the authors identified three types of medical careers: "Committed-satisfied with career", which are physicians committed to their work the most with the highest level of work stress; "Clever-satisfied with life", the least committed to their work, but deriving the most benefit from it; and "Bright—competent", which are the most competent, but with problems managing their lives. The "Committed" type proved to be at the highest risk of BS, whereas "Clever" at the lowest [46-50]. Other papers in our review have also identified individual character or personality traits as potentially significant factors. For example, Ogińska-Bulik et al. showed a greater severity of BS in healthcare professionals with type D personality [37]. On the other hand, Orzechowska et al. emphasized the protective importance of a strong internal locus of control [40], whereas Walocha et. al. of high level of empathy [44]. It may suggest that there are individuals who are a priori more susceptible to BS due to their personality. Brown et al. proposed specific personality traits that may particularly contribute to BS: neuroticism, agreeableness, and conscientiousness [77]. Pejušković et al. examined doctors for personality dimensions, stress coping strategies and the level of BS and noticed that harm avoidance led to a more common occurrence of BS, while self-directedness and cooperativeness were significantly more prevalent features in physicians with a lower level of BS [78].

From personal resources, the protective role against BS has been proven for, among others, satisfaction with social and family life, freedom, happiness, mature love, self-respect and a high level of support provided by superiors and co-workers [42,45-50].

\subsection{Interventions to Prevent BS}

There is a large variety of possibilities of BS-focused interventions in doctors. In general, they may be classified in two main categories: interventions directed on the individuals and these targeting organization as a whole $[79,80]$. Physician-directed interventions may include cognitive behavioral therapy, training of communication skills, stress-coping strategies, creation support groups or improvement of opportunities for professional growth. Examples of organization-directed interventions can be given: rescheduling, reductions in the workload, greater institutional support, systematization of work and duties division. In the past few years, two important systematic reviews and metanalyses on this topic have been published [81,82]. The article by Panagioti et al. indicated 
that, unfortunately, intervention focused on decreasing BS in physicians were associated with rather small benefits. They underlined that organization-directed approaches might be slightly more effective than those geared to the individual. A review conducted by West et al., however, indicated that both individual-focused and organizational-focused approaches may be beneficial and suggested a combination of both tactics. Furthermore, in 2017 scientists from the Mayo Clinic have published their experiences with implementing organizational strategies therein and claimed that many simple and affordable interventions are effective, yet proper leadership and sustained attention seem to be the keys to success [83]. Currently, a clinical trial named Internet-Based Intervention for Occupational Stress Among Medical Professionals (Med-Stress) is carried out in Poland. It aims to examine the effectiveness of cognitive-behavioral therapyframed internet intervention for reduction of occupational stress, BS and depression (NCT03475290) [84]. Such affordable yet effective strategies might be the light at the end of the tunnel for doctors in Poland and abroad.

\subsection{Advantages and Limitations of the Study}

This review has several limitations that need to be mentioned. Above all, no quantitative analysis was performed due to the variety of tools used to assess the phenomenon of BS. Moreover, most commonly those studies did not allow dichotomous statement of burnout or the lack thereof, but rather indicated the existence and severity of some symptoms and it is therefore difficult to draw conclusions regarding the overall prevalence of this phenomenon. The included studies also did not cover doctors of all specialties and settings, so it is not entirely clear whether the conclusions drawn can be extrapolated to all doctors practicing in Poland. Another aspect relevant for interpretation limitation is the fact that the studies included in this review were mostly of medium or low reliability.

Nevertheless, to our knowledge no systematic review of the topic of BS in Polish doctors has been published to date. Therefore, this article is the most recent summary of available knowledge about BS in polish physicians in many aspects: prevalence, severity, its risk and protective factors. Moreover, it indicates the existing gaps in knowledge about this phenomenon, which we hope will become a trigger for further studies in this field. Despite the gaps in knowledge, based solely on the available research, it can be concluded with great certainty that the BS problem among Polish physicians is vivid; therefore, preventive and therapeutic actions should no longer be postponed. This is an important signal for both policy makers and physicians themselves.

\section{Conclusions}

BS is a multidimensional phenomenon that depends on various factors, such as personality traits, the nature of the work, management in the healthcare system, and many others. The results of individual studies are diverse, which makes it difficult to draw specific conclusions. However, the problem of burnout among Polish doctors is vivid and worth special attention from society, health policy leaders, and doctors themselves. High-quality research is essential for a better understanding of this topic.

Supplementary Materials: The following are available online at http://www.mdpi.com/1660-4601/16/24/5026/s1, Figure S1: PRISMA 2009 Flow Diagram, Table S1: Risk of bias assessment with the use of modified and adapted Newcastle-Ottawa Scale, Table S2. Principles of awarding points to individual publications.

Author Contributions: Conceptualization, M.Z., S.Z., M.C., K.K.-K.; methodology, M.Z., S.Z. software, M.Z.; validation, M.C., K.K.-K.; formal analysis, M.Z., S.Z., M.C., K.K.-K.; investigation, M.Z., S.Z., M.C., K.K.-K.; resources, M.Z., S.Z., M.C., K.K.-K.; data curation, M.Z., S.Z., M.C., K.K.-K.; Writing-Original draft preparation: M.Z., S.Z.; Writing-Review and editing, M.C., K.K.-K.; visualization, M.Z., S.Z.; supervision, M.C., K.K.-K.; project administration, M.Z., S.Z., M.C., K.K.-K.; funding acquisition, M.Z., S.Z., M.C., K.K.-K.

Funding: This study was funded by The Center of Postgraduate Medical Education (501-1-022-26-19).

Conflicts of Interest: The authors declare no conflict of interest. 


\section{References}

1. Freudenberger, H.J. Staff Burn-Out. J. Soc. Issues 1974, 30, 159-165. [CrossRef]

2. Maslach, C. Burned-out. Hum. Behav. 1976, 5, 16-22.

3. Maslach, C.; Jackson, S.E. Maslach Burnout Inventory: Manual, 2nd ed.; 577 College Ave., Palo Alto 94306; Consulting Psychologists Press: Palo Alto, CA, USA, 1986.

4. Gil-Monte, P.R. Factorial validity of the Maslach Burnout Inventory (MBI-HSS) among Spanish professionals. Revista de Saúde Pública 2005, 39, 1-8. [CrossRef]

5. Santinello, M. Link Burnout Questionnaire; Giunti OS: Firenze, Italy, 2007.

6. Steuden, S.; Okła, W. Tymczasowy podręcznik Skali Wypalenia Sił (SWS); Wersja eskperymentalna; Zakład Psychologii Klinicznej KUL: Lublin, Poland, 1998.

7. Rotenstein, L.S.; Torre, M.; Ramos, M.A.; Rosales, R.C.; Guille, C.; Sen, S.; Mata, D.A. Prevalence of Burnout Among Physicians: A Systematic Review. JAMA 2018, 320, 1131-1150. [CrossRef]

8. Glebocka, A. The Relationship Between Burnout Syndrome Among the Medical Staff and Work Conditions in the Polish Healthcare System. Adv. Exp. Med. Biol. 2017, 968, 61-70. [CrossRef]

9. Health Consumer Powerhouse. In Euro Health Consumer Index; Health Consumer Powerhouse Ltd.: Marseillan, France, 2018.

10. World Health Organisation. Global Health Expenditure Database; World Health Organisation: Geneva, Switzerland, 2016.

11. Sowada, C.; Sagan, A.; Kowalska-Bobko, I.; Badora-Musiał, K.; Bochenek, T.; Domagała, A.; Dubas-Jakóbczyk, K.; Kocot, E.; Mrożek-Gąsiorowska, M.; Sitko, S.; et al. Poland: Health system review. Health Syst. Transit. 2019, 21, $1-235$.

12. Eurostat. Healthcare Personnel Statistics_Physicians; Statistics Explained; Eurostat: Luxemburg, 2018.

13. OECD/EU. Health at a Glance: Europe 2018: State of Health in the EU Cycle; OECD Publishing: Paris, Fance; Brussels, Belgium, 2018. [CrossRef]

14. Dabrowski, F. Junior Doctors Go on Hunger Strike in Poland BMJ Opinion 21 December 2017. Available online: https://blogs.bmj.com/bmj/2017/12/21/filip-a-dabrowski-junior-doctors-go-on-hunger-strike-inpoland/ (accessed on 20 October 2019).

15. BBC News: Polish Doctors on Hunger Strike in Healthcare Row. Available online: https://www.bbc.com/ news/world-europe-41777785 (accessed on 20 October 2019).

16. Bettany, K. Junior doctors rise up in Poland. BMJ 2016, 353, i3472. [CrossRef]

17. Okręgowa Izba Lekarska w Warszawie. Available online: https://polskatochorykraj.pl (accessed on 20 October 2019).

18. Wallace, J.E.; Lemaire, J.B.; Ghali, W.A. Physician wellness: A missing quality indicator. Lancet 2009, 374, 1714-1721. [CrossRef]

19. Kuerer, H.M.; Eberlein, T.J.; Pollock, R.E.; Huschka, M.; Baile, W.F.; Morrow, M.; Michelassi, F.; Singletary, S.E.; Novotny, P.; Sloan, J.; et al. Career satisfaction, practice patterns and burnout among surgical oncologists: Report on the quality of life of members of the Society of Surgical Oncology. Ann. Surg. Oncol. 2007, 14, 3043-3053. [CrossRef]

20. West, C.P.; Shanafelt, T.D.; Kolars, J.C. Quality of life, burnout, educational debt, and medical knowledge among internal medicine residents. JAMA 2011, 306, 952-960. [CrossRef]

21. Wurm, W.; Vogel, K.; Holl, A.; Ebner, C.; Bayer, D.; Morkl, S.; Szilagyi, I.S.; Hotter, E.; Kapfhammer, H.P.; Hofmann, P. Depression-Burnout Overlap in Physicians. PLoS ONE 2016, 11, e0149913. [CrossRef]

22. Stehman, C.R.; Testo, Z.; Gershaw, R.S.; Kellogg, A.R. Burnout, Drop Out, Suicide: Physician Loss in Emergency Medicine, Part, I. West. J. Emerg. Med. 2019, 20, 485-494. [CrossRef]

23. Oquendo, M.A.; Bernstein, C.A.; Mayer, L.E.S. A Key Differential Diagnosis for Physicians-Major Depression or Burnout? JAMA Psychiatry 2019, 6, 1111-1112. [CrossRef] [PubMed]

24. Wilkinson, H.; Whittington, R.; Perry, L.; Eames, C. Examining the relationship between burnout and empathy in healthcare professionals: A systematic review. Burn. Res. 2017, 6, 18-29. [CrossRef] [PubMed]

25. Panagioti, M.; Geraghty, K.; Johnson, J.; Zhou, A.; Panagopoulou, E.; Chew-Graham, C.; Peters, D.; Hodkinson, A.; Riley, R.; Esmail, A. Association Between Physician Burnout and Patient Safety, Professionalism, and Patient Satisfaction: A Systematic Review and Meta-analysis. JAMA Intern. Med. 2018, 178, 1317-1330. [CrossRef] [PubMed] 
26. Dewa, C.S.; Loong, D.; Bonato, S.; Trojanowski, L. The relationship between physician burnout and quality of healthcare in terms of safety and acceptability: A systematic review. BMJ Open 2017, 7, e015141. [CrossRef]

27. Shanafelt, T.D.; Mungo, M.; Schmitgen, J.; Storz, K.A.; Reeves, D.; Hayes, S.N.; Sloan, J.A.; Swensen, S.J.; Buskirk, S.J. Longitudinal Study Evaluating the Association Between Physician Burnout and Changes in Professional Work Effort. Mayo Clin. Proc. 2016, 91, 422-431. [CrossRef]

28. Dewa, C.S.; Loong, D.; Bonato, S.; Thanh, N.X.; Jacobs, P. How does burnout affect physician productivity? A systematic literature review. BMC Health Serv. Res. 2014, 14, 325. [CrossRef]

29. Shanafelt, T.D.; Balch, C.M.; Bechamps, G.; Russell, T.; Dyrbye, L.; Satele, D.; Collicott, P.; Novotny, P.J.; Sloan, J.; Freischlag, J. Burnout and medical errors among American surgeons. Ann. Surg. 2010, 251, 995-1000. [CrossRef]

30. Chen, K.Y.; Yang, C.M.; Lien, C.H.; Chiou, H.Y.; Lin, M.R.; Chang, H.R.; Chiu, W.T. Burnout, job satisfaction, and medical malpractice among physicians. Int. J. Med. Sci. 2013, 10, 1471-1478. [CrossRef]

31. Prins, J.T.; van der Heijden, F.M.; Hoekstra-Weebers, J.E.; Bakker, A.B.; van de Wiel, H.B.; Jacobs, B.; Gazendam-Donofrio, S.M. Burnout, engagement and resident physicians' self-reported errors. Psychol. Health Med. 2009, 14, 654-666. [CrossRef] [PubMed]

32. Wen, J.; Cheng, Y.; Hu, X.; Yuan, P.; Hao, T.; Shi, Y. Workload, burnout, and medical mistakes among physicians in China: A cross-sectional study. Biosci. Trends 2016, 10, 27-33. [CrossRef] [PubMed]

33. Halbesleben, J.R.; Rathert, C. Linking physician burnout and patient outcomes: Exploring the dyadic relationship between physicians and patients. Health Care Manag. Rev. 2008, 33, 29-39. [CrossRef] [PubMed]

34. Hall, L.H.; Johnson, J.; Watt, I.; Tsipa, A.; O'Connor, D.B. Healthcare Staff Wellbeing, Burnout, and Patient Safety: A Systematic Review. PLoS ONE 2016, 11, e0159015. [CrossRef]

35. Wells, G.A.; Shea, B.; O'Connell, D.; Peterson, J.; Welch, V.; Losos, M.; Tugwell, P. The Newcastle-Ottawa Scale (NOS) for Assessing the Quality of Nonrandomised Studies in Meta-Analyses. Available online: http://www.ohri.ca/programs/clinical_epidemiology/oxford.asp (accessed on 28 October 2019).

36. Czekajska-Chehab, E.; Okla, W.; Drop, A.; Skrzypek, M. The professional burnout syndrome in radiologists. Ann. Univ. Mariae Curie Sklodowska Med. 2003, 58, 254-260.

37. Oginska-Bulik, N. Occupational stress and its consequences in healthcare professionals: The role of type D personality. Int. J. Occup. Med. Environ. Health 2006, 19, 113-122. [CrossRef]

38. Głębocka, A.; Lisowska, E. Professional burnout and stress among polish physicians explained by the Hobfoll resources theory. J. Physiol. Pharmacol. 2007, 58, 243-252.

39. Kulik, M.M. Cierpienie, które przerasta, czyli o wypaleniu lekarzy pracujacych z ludźmi przewlekle chorymi. Studia z psychologii w KUL. Wyd. KUL 2008, 15, 81-112.

40. Orzechowska, A.; Talarowska, M.; Drozda, R.; Mirowska, D.; Florkowski, A.; Zboralski, K.; Gałecki, P. The burnout syndrome among doctors and nurses. Polski Merkuriusz Lekarski 2008, 25, 507-509.

41. Soler, J.K.; Yaman, H.; Esteva, M.; Dobbs, F.; Asenova, R.S.; Katić, M.; Ožvačić, Z.; Desgranges, J.P.; Moreau, A.; Lionis, C. Burnout in European family doctors: The EGPRN study. Fam. Pract. 2008, 25, 245-265. [CrossRef]

42. Wojtyna, E.; Stawiarska, P. Humor styles and psychosocial working conditions in relation to occupational burnout among doctors. Pol. Psychol. Bull. 2009, 40, 20-28. [CrossRef]

43. Mróz, B.; Turkiewicz, A.; Mordarski, S. Wypalenie zawodowe wśród personelu intensywnej opieki medycznej. Polskie Forum Psychologiczne. 2010, 2, 212-226.

44. Walocha, E.; Tomaszewski, K.A.; Wilczek-Ruzyczka, E.; Walocha, J. Empathy and burnout among physicians of different specialities. Folia Med. Cracov. 2013, 53, 35-42.

45. Gaszynska, E.; Stankiewicz-Rudnicki, M.; Szatko, F.; Wieczorek, A.; Gaszynski, T. Life satisfaction and work-related satisfaction among anesthesiologists in Poland. Sci. World J. 2014, 2014, 601865. [CrossRef]

46. Tartas, M.; Walkiewicz, M.; Majkowicz, M.; Budzinski, W. Psychological factors determining success in a medical career: A 10-year longitudinal study. Med. Teach. 2011,33, e163-e172. [CrossRef]

47. Walkiewicz, M.; Tartas, M.; Majkowicz, M.; Budzinski, W. Academic achievement, depression and anxiety during medical education predict the styles of success in a medical career: A 10-year longitudinal study. Med. Teach. 2012, 34, e611-e619. [CrossRef]

48. Tartas, M.; Walkiewicz, M.; Budzinski, W.; Majkowicz, M.; Wojcikiewicz, K. The sense of coherence and styles of success in the medical career: A longitudinal study. BMC Med. Educ. 2014, 14, 254. [CrossRef]

49. Tartas, M.; Walkiewicz, M.; Budzinski, W.; Majkowicz, M.; Wojcikiewicz, K.; Zdun-Ryzewska, A. The coping strategies during medical education predict style of success in medical career: A 10-year longitudinal study. BMC Med. Educ. 2016, 16, 186. [CrossRef] 
50. Budzinski, W.; Walkiewicz, M.; Tartas, M. The system of values and styles of success in the medical career: A longitudinal study. Int. J. Occup. Med. Environ. Health 2018, 31, 823-835. [CrossRef]

51. Misiolek, A.; Gorczyca, P.; Misiolek, H.; Gierlotka, Z. The prevalence of burnout syndrome in Polish anaesthesiologists. Anaesthesiol. Intensive Ther. 2014, 46, 155-161. [CrossRef]

52. Misiołek, A.; Gil-Monte, P.R.; Misiołek, H. Prevalence of burnout in Polish anesthesiologists and anesthetist nursing professionals: A comparative non-randomized cross-sectional study. J. Health Psychol. 2017, 22, 465-474. [CrossRef]

53. Grabowski, D.; Chudzicka-Czupała, A.; Chrupała-Pniak, M.; Rachwaniec-Szczecińska, Ż.; Stasiła-Sieradzka, M.; Wojciechowska, W. Work ethic, organizational commitment and burnout. Med. Pr. 2019, 70, 305-316. [CrossRef]

54. Leszczyński, P.; Panczyk, M.; Podgórski, M.; Owczarek, K.; Gałązkowski, R.; Mikos, M.; Charuta, A.; Zacharuk, T.; Gotlib, J. Determinants of occupational burnout among employees of the Emergency Medical Services in Poland. Ann. Agric. Environ. Med. 2019, 26, 114-119. [CrossRef]

55. Makara-Studzinska, M.; Zaluski, M.; Tylec, A.; Panasiuk, L. Do Polish doctors suffer from occupational burnout syndrome? An attempt to find an answer-Pilot study. Ann. Agric. Environ. Med. 2019, 26, 191-197. [CrossRef]

56. Kumar, S. Burnout and Doctors: Prevalence, Prevention and Intervention. Healthcare 2016, 4, 37. [CrossRef]

57. Alexandrova-Karamanova, A.; Todorova, I.; Montgomery, A.; Panagopoulou, E.; Costa, P.; Baban, A.; Davas, A.; Milosevic, M.; Mijakoski, D. Burnout and health behaviors in health professionals from seven European countries. Int. Arch. Occup. Environ. Health 2016, 89, 1059-1075. [CrossRef]

58. Nazir, A.; Smalbrugge, M.; Moser, A.; Karuza, J.; Crecelius, C.; Hertogh, C.; Feldman, S.; Katz, P.R. The Prevalence of Burnout Among Nursing Home Physicians: An International Perspective. J. Am. Med. Dir. Assoc. 2018, 19, 86-88. [CrossRef]

59. Purvanova, R.M.; Muros, J.P. Gender differences in burnout: A meta-analysis. J. Vocat. Behav. 2010, 77, 168-185. [CrossRef]

60. LaFaver, K.; Miyasaki, J.M.; Keran, C.M.; Rheaume, C.; Gulya, L.; Levin, K.H.; Jones, E.C.; Schwarz, H.B.; Molano, J.R.; Hessler, A.; et al. Age and sex differences in burnout, career satisfaction, and well-being in US neurologists. Neurology 2018, 91, e1928-e1941. [CrossRef]

61. Marchalik, D.; Brems, J.; Rodriguez, A.; Lynch, J.H.; Padmore, J.; Stamatakis, L.; Krasnow, R. The Impact of Institutional Factors on Physician Burnout: A National Study of Urology Trainees. Urology 2019, 131, 27-35. [CrossRef]

62. Burns, K.E.A.; Fox-Robichaud, A.; Lorens, E.; Martin, C.M. Canadian Critical Care Society. Gender differences in career satisfaction, moral distress, and incivility: A national, cross-sectional survey of Canadian critical care physicians. Can. J. Anaesth. 2019, 66, 503-511. [CrossRef]

63. Amoafo, E.; Hanbali, N.; Patel, A.; Singh, P. What are the significant factors associated with burnout in doctors? Occup. Med. 2015, 65, 117-121. [CrossRef]

64. Dyrbye, L.N.; Burke, S.E.; Hardeman, R.R.; Herrin, J.; Wittlin, N.M.; Yeazel, M.; Dovidio, J.F.; Cunningham, B.; White, R.O.; Phelan, S.M.; et al. Association of Clinical Specialty With Symptoms of Burnout and Career Choice Regret Among US Resident Physicians. JAMA 2018, 320, 1114-1130. [CrossRef]

65. Supreme Medical Council of Poland 2019. Available online: https://www.nil.org.pl/_data/assets/pdf_file/ 0019/140518/zestawienie-nr-3.pdf (accessed on 20 October 2019).

66. Busis, N.A.; Shanafelt, T.D.; Keran, C.M.; Levin, K.H.; Schwarz, H.B.; Molano, J.R.; Vidic, T.R.; Kass, J.S.; Miyasaki, J.M.; Sloan, J.A.; et al. Burnout, career satisfaction, and well-being among US neurologists in 2016. Neurology 2017, 88, 797-808. [CrossRef]

67. Sanfilippo, F.; Noto, A.; Foresta, G.; Santonocito, C.; Palumbo, G.J.; Arcadipane, A.; Maybauer, D.M.; Maybauer, M.O. Incidence and Factors Associated with Burnout in Anesthesiology: A Systematic Review. Biomed. Res. Int. 2017, 2017, 8648925. [CrossRef]

68. Shanafelt, T.D.; Boone, S.; Tan, L.; Dyrbye, L.N.; Sotile, W.; Satele, D.; West, C.P.; Sloan, J.; Oreskovich, M.R. Burnout and satisfaction with work-life balance among US physicians relative to the general US population. Arch. Intern. Med. 2012, 172, 1377-1385. [CrossRef]

69. Trufelli, D.C.; Bensi, C.G.; Garcia, J.B.; Narahara, J.L.; Abrao, M.N.; Diniz, R.W.; Miranda Vda, C.; Soares, H.P.; Del Giglio, A. Burnout in cancer professionals: A systematic review and meta-analysis. Eur. J. Cancer Care 2008, 17, 524-531. [CrossRef] 
70. Fothergill, A.; Edwards, D.; Burnard, P. Stress, burnout, coping and stress management in psychiatrists: Findings from a systematic review. Int. J. Soc. Psychiatry 2004, 50, 54-65. [CrossRef]

71. Dimou, F.M.; Eckelbarger, D.; Riall, T.S. Surgeon Burnout: A Systematic Review. J. Am. Coll. Surg. 2016, 222, 1230-1239. [CrossRef]

72. Roy, A.; van der Weijden, T.; de Vries, N. Relationships of work characteristics to job satisfaction, turnover intention, and burnout among doctors in the district public-private mixed health system of Bangladesh. BMC Health Serv. Res. 2017, 17, 421. [CrossRef]

73. Pulcrano, M.; Evans, S.R.; Sosin, M. Quality of Life and Burnout Rates Across Surgical Specialties: A Systematic Review. JAMA Surg. 2016, 151, 970-978. [CrossRef]

74. Anil, M.; Yurtseven, A.; Yurtseven, I.; Ulgen, M.; Anil, A.B.; Helvaci, M.; Aksu, N. The evaluation of burnout and job satisfaction levels in residents of pediatrics. Türk Pediatri Arşivi 2017, 52, 66-71. [CrossRef]

75. Holmes, E.G.; Connolly, A.; Putnam, K.T.; Penaskovic, K.M.; Denniston, C.R.; Clark, L.H.; Rubinow, D.R.; Meltzer-Brody, S. Taking Care of Our Own: A Multispecialty Study of Resident and Program Director Perspectives on Contributors to Burnout and Potential Interventions. Acad. Psychiatry 2017, 41, 159-166. [CrossRef]

76. Dyrbye, L.N.; Varkey, P.; Boone, S.L.; Satele, D.V.; Sloan, J.A.; Shanafelt, T.D. Physician satisfaction and burnout at different career stages. Mayo Clin. Proc. 2013, 88, 1358-1367. [CrossRef]

77. Brown, P.A.; Slater, M.; Lofters, A. Personality and burnout among primary care physicians: An international study. Psychol. Res. Behav. Manag. 2019, 12, 169-177. [CrossRef]

78. Pejuskovic, B.; Lecic-Tosevski, D.; Priebe, S.; Toskovic, O. Burnout syndrome among physicians-The role of personality dimensions and coping strategies. Psychiatr. Danub. 2011, 23, 389-395.

79. Awa, W.L.; Plaumann, M.; Walter, U. Burnout prevention: A review of intervention programs. Patient Educ. Couns. 2010, 78, 184-190. [CrossRef]

80. Regehr, C.; Glancy, D.; Pitts, A.; LeBlanc, V.R. Interventions to reduce the consequences of stress in physicians: A review and meta-analysis. J. Nerv. Ment. Dis. 2014, 202, 353-359. [CrossRef]

81. Panagioti, M.; Panagopoulou, E.; Bower, P.; Lewith, G.; Kontopantelis, E.; Chew-Graham, C.; Dawson, S.; van Marwijk, H.; Geraghty, K.; Esmail, A. Controlled Interventions to Reduce Burnout in Physicians: A Systematic Review and Meta-analysis. JAMA Intern. Med. 2017, 177, 195-205. [CrossRef]

82. West, C.P.; Dyrbye, L.N.; Erwin, P.J.; Shanafelt, T.D. Interventions to prevent and reduce physician burnout: A systematic review and meta-analysis. Lancet 2016, 388, 2272-2281. [CrossRef]

83. Shanafelt, T.D.; Noseworthy, J.H. Executive Leadership and Physician Well-being: Nine Organizational Strategies to Promote Engagement and Reduce Burnout. Mayo Clin. Proc. 2017, 92, 129-146. [CrossRef]

84. Smoktunowicz, E.; Lesnierowska, M.; Cieslak, R.; Carlbring, P.; Andersson, G. Efficacy of an Internet-based intervention for job stress and burnout among medical professionals: Study protocol for a randomized controlled trial. Trials 2019, 20, 338. [CrossRef]

(C) 2019 by the authors. Licensee MDPI, Basel, Switzerland. This article is an open access article distributed under the terms and conditions of the Creative Commons Attribution (CC BY) license (http://creativecommons.org/licenses/by/4.0/). 